The Maastricht Journal of Liberal Arts

(C) S. Tosatto

2019, Volume Eleven, 57-70

\title{
WHO KILLED THE TPP?
}

\section{An evaluation of societal influence upon the decision of the US' withdrawal from the Trans-Pacific Partnership}

Silvia Tosatto

\begin{abstract}
This paper investigates the conditions which led the United States to withdraw from the Trans-Pacific Partnership Trade agreement. The funnel of causality framework is used to determine which causes were mostly predominant in leading to this foreign policy decision. The paper will examine the impact of societal sources, specifically public opinion, media coverage, Congressional approval processes, and interest groups. The role of each group is analysed within the context of the 2016 Presidential elections. The paper concludes that public opinion, amplified by media, is the source of Congress' opposition, and having trumped major interest groups, public opinion has evidently contributed to US' withdraw from the Trans-Pacific Partnership.
\end{abstract}

\section{Introduction}

The Trans-Pacific Partnership (TPP) is a trade agreement that aimed to eliminate tariffs and other barriers to trade between countries bordering the Pacific Ocean (Kaufman, 2017). In 2017 it was estimated that this trade agreement would sur- 
pass the North American Trade Agreement (NAFTA), becoming the largest in the world. The United States entered negotiations under the Bush administration, but it was only under Obama in February 2016 that the US, along with eleven other countries, signed the trade agreement (Hastendt, 2017). The policy was compatible with Obama's "pivot to Asia" strategy, which aimed at increasing US attention to the Asian Pacific (Hastendt, 2017; McBride, 2017). The signing of this record-breaking trade agreement was going against a protracted crisis in international trade, represented by an increase in Non-Tariff Barriers and a slowing down of trade (Petri \& Plummer, 2016).

But US participation in the TPP did not last. One year after the signing of the agreement, the newly elected president Donald J. Trump officially withdrew from it within his first week of office (Baker, 2017). Before that, the Obama administration had refused to submit the Trade Agreement for Congressional approval in 2016, sure of its rejection (Yuhas, 2016). In addition, the agreement seemed to have been the object of criticism of almost all candidates during the campaign leading up to the Presidential elections (Skonieczny, 2017).

This paper will investigate the causes which led to the US' withdraw from the TPP. By applying the funnel of causality model, a framework of evaluation commonly used in American Foreign Policy Analysis, the paper will present how the societal sources gained major influence upon the above-mentioned policy. The impact of public opinion, media, Congress, and interest groups will be evaluated. Ultimately, the paper argues that the emergence of a protectionist public opinion affected other sources and majorly contributed to US' withdraw from the TPP. By considering the role played by the public in this important decision, this paper contributes to increasing academic awareness upon how, through globalisation, public opinion has become more engaged in American Foreign Trade policy.

The paper, while initially dedicated to a scholarly audience devoted to the study of International Relations, can provide important insights to Political Sciences and International Economics students. The observations here presented provide a relevant foundation necessary to understand how both the democratic process and domestic economic concerns derived from international market competition can influence the evolution of foreign policy.

\section{Levels of analysis of foreign policy}

The funnel of causality framework was initially employed as a tool to explain voting behaviour during American elections by public opinion researchers in the 1970s. It was first employed in the context of policy analysis by Richard 
Hofferbert in 1974, to aid scholars to gain insight within the process of policy making. Its robust theoretical foundation was considered to be its strongest feature by many academics at the time. In fact, the framework elaborated upon how different variables can interact or act independently to produce decisional outcomes (Wilder, 2015). This logic proved to be extremely relevant in the field of political sciences, as it led not only to the fragmentation of the broader field into many sub-fields, but because it also advanced an important methodology suitable for policy-making analysis. While opponents of the theory have criticised it for failing to establish a singular and clear theoretical ground, the funnel of causality is still relevantly employed nowadays to explain the influences of institutional and sociological contexts upon the realm of policy-making (Wilder, 2016). Based upon these logical foundations, throughout the years scholars have advanced different variables as analytical tools to evaluate new developments of policy-making.

In this paper, a version of the theory advanced by Rosenau (as cited in Wittkopf, Jones, \& Kegley, 2007) will be employed. Rosenau's funnel of causality adapts five variables needed to reflect specifically sources of American foreign policy. These variables can be subdivided into five categories, namely external, societal, governmental, role, and individual sources. While external sources are identified to be all the characteristics of the international system, outside the US, societal sources refer to attributes of the domestic political and social system with regards to foreign outlook. Similarly, governmental sources describe the impact which the governmental structure has on foreign policy making, and role sources refer to the influence which certain roles in the decision-making process have upon the behaviour of who sits on the chair. Lastly, individual sources comprise the characteristics of presidents which differentiate them from one another (Wittkopf et al., 2007).

This essay will focus on the societal causes to analyse the decision to withdraw the US from the TPP. Nonetheless, this author is aware that this policy was not only the result of the here described causes. Because of societal sources' often disregarded role in foreign policy analysis, a focus has been placed on the influence of public opinion, media, Congress, and interest groups. These factors will all be evaluated and compared to determine which one had the heaviest impact upon the policy outcome. A literature review of academic articles, news pieces, public polls, and scholarly studies will be employed to examine how societal sources have influenced Trump's decision to withdraw from the Partnership. 


\section{A shifting public opinion: the 2016 elections and protectionism}

American public opinion is described by many analysts as generally uninformed about foreign policy (Hastendt, 2017). The case of the Trans-Pacific Partnership was indeed no exception to such a trend. In a 2015 poll, 48\% of Americans declared to have heard 'nothing at all' concerning the TPP, and 30\% confirmed to have heard 'not much' (New York Times, 2015). During elections, analysts argue that public opinion does not provide a popular mandate to election winners (Hastendt, 2017). For such reasons, public opinion is not considered influential in elections with regards to a candidate's foreign policy positions.

Nevertheless, distinctions should be made within foreign policy decisions. While the above-mentioned position might be valid in electoral debates such military interventions, the case for economic foreign policy might be different. In fact, policies like international trade, while still being characterised by public ignorance, are of primary importance during elections for the public. This is true because of their impact upon the domestic economy, and the state of the economy has influenced presidential elections for a long portion of American History (Lynch, 1999). This makes the public highly sensitive to candidates' positions on economic policies, specifically if these are perceived to be a solution to issues which affect them directly, as it was the case during the 2016, as it will be later exposed.

When Barack Obama signed the Trans-Pacific Partnership in February 2016, the US public was following the primaries of the Democratic and Republican party for the 2016 Presidential election. In general, protectionism was largely present in candidates' campaigns (Calmes, 2016c). The Trans-Pacific Partnership, being a free trade agreement, was hence a point of debate present since the beginning of the campaign. Furthermore, the economic context of some states was very susceptible to trade. In fact, the competition of Chinese imports with the US manufacturing sector between 1997 to 2011 had heavily impacted states with strong manufacturing sectors such as North Carolina and Pennsylvania (Acemoglu, Autor, Dorn, Hanson, \& Prince, 2016; Autor, Dorn, Hanson, \& Majlesi, 2016). Therefore, the economic context of the years preceding the election established a fertile ground for voters' protectionist attitudes.

Presidential candidates started voicing opinions about the trade deal as early as 2015 (The New York Times, 2018). Bernie Sanders within the Democratic party, and Donald Trump within the Republican, emerged holding the strongest views in relation to trade. Both candidates were categorically opposed to the agreement negotiated by Obama for different reasons. Sanders perceived the TPP and globalisation to be a threat to the interests of "middle-class and working fam- 
ilies', while Trump argued more generally for 'defending American jobs', specifically meant as American industrial jobs (Sutter, 2016). Hence, both parties had candidates who defended protectionist views.

Such views resembled common sentiment shared within the American public opinion. A poll published by the New York Times (2015) at the beginning of the presidential campaign clearly indicated that most Americans considered trade restrictions to be necessary to protect domestic industries. Most citizens seemed to link job losses within the manufacturing sector to the increase of foreign competition stimulated by freer global trade (Williams, 2013). Furthermore, economists seemed to have concerns regarding manufacturing sector employment and called out for more caution large trade agreements negotiations (Piketty, 2016). Evidently, there was a lack of support for free trade and pro-globalisation policy within a large spectrum of the American public, which resonated with Sanders' and Trump's campaigns.

Consequently, their positions and public's preference for protectionism, pushed other candidates within both parties to assume similar anti-trade stances to ensure voters' support (Rodrik, 2017). For instance, Hilary Clinton was quickly forced to oppose the TPP in 2015, although she had helped negotiate the deal while being Obama's Secretary of State (Chozick \& Flegenheimer, 2016). On the other side too, Trump's grievance of Republican's departure from the "Grand Old Protectionists" ideas of the 1930s convinced the party to favour candidates opposed to the TPP (Irwin, 2017). Thus, by the end of the primaries, all candidates left opposed the TPP, and although the Democratic nomination was not won by Sanders, Clinton was forced to adjust to her views to gain votes.

Ultimately, we can see how the public's favour of protectionism influenced the 2016 elections from the very beginning, leading even economically liberal candidates such as Hilary Clinton to voice opposition towards the Trans-Pacific Partnership in their campaign.

\section{The 2016 elections: media's coverage and public opinion}

Elections are largely covered by the media, and media messaging also contributes to model public opinion. Additionally, factors like priming and larger coverage represent a relevant tool of influence for the media. Since the TPP and trade were largely present during the election it is important to analyse the impact of media upon the public opinion in relation to both foreign policy aspects. As the media have an agenda-setting role for public opinion, their coverage of candidates and debates can be considered to have a great influence during elections; 
in fact, what is covered within the news, and how, will impact the perception of the public (McCombs, 2002). For instance, larger coverage of trade as opposed to environmental policy will lead the public to consider trade as more important. Priming is another characteristic of media influence. The public bases its opinion upon the agenda that is set by mass media sources, which will consequently stick more strongly in the minds of listeners (McCombs, 2002). It follows that public opinion, when following events with large content such as elections, will only focus on topics at the top of the media's agenda.

Evidence shows that between the early stages of the 2016 campaign and the end of the race, Donald Trump received more press attention than any other candidate. His tweets, comments, and policy opinions were most often reported at the top of media outlets. Generally, Trump enjoyed 15\% more media coverage compared to Hilary Clinton (Patterson, 2016). This meant that slogans such as 'America First', the epitome of his protectionist preferences, were often at the centre of media reports, and hence left a mark upon public opinion.

In addition, on most media channels Hilary Clinton's policy positions were most frequently expressed through the words of her main opponents. For instance, Clinton's position on trade was often reported only in the context of opponent's criticisms (Patterson, 2016). This weakened public opinion's attention to Clinton at the advantage of opponents such as Trump. Consequently, this contributed to undermine her stances with regards to policy such as the TPP. Hence, Clinton's trade policy was not only less evident to the public due to its limited platform, but it was also crippled by the media's reporting.

Therefore, it is evident that media had a significant effect upon the public perception of trade policy advanced by the parties' nominees. As a matter of fact, at the beginning of the campaigns the majority of the public still carried a favourable view of the deal. However, specifically among republicans, the perspective changed after the first weeks of the campaign (Calmes, 2016c). Clearly, the larger coverage that the Trump campaign was receiving on the news and Trump's emphasis upon protectionism did strike the attention of the American public. Thus, Trump not only enjoyed a larger media platform for his ideas compared to Clinton, but was able to enjoy the benefit of primacy, and hence more public attention concerning policy positions. With regards to trade, this primacy benefit along with the undermined position of the opponent ensured that Trump's impact upon public opinion was thus more than Clinton's. In the context of the funnel of causality framework, it is evident that the Media had a corroborating effect upon public's perception of the candidates' campaigns and upon their positions with regards to trade. 


\section{Congress: concerns on the left, concerns on the right}

To fully understand the impact which the candidates opposing trade had on the TPP's destiny, it is essential to scrutinise how Congress' position towards the policy has evolved over time. After an initial support of the president's initiative in the negotiation of the trade deal, representatives' attitudes appeared to shift according to primaries' results and the evolution of the presidential run.

The TPP saga in Congress started in June 2015, when Obama received from both the Senate and the House of Representatives enhanced negotiation powers. This entailed that Congress would not be able to amend the agreements but would only be able to approve or repeal them, giving the President authority to carry on with the negotiations (Butensky, 2016). This was not achieved easily. While Republicans where generally in favour of the negotiations, several Democrats were concerned about job losses which manufacturing industries would suffer in the aftermath of the Agreement. Democrats where pushing for the approval of a Trade Adjustment Assistance (TAA), which contained provisions such as trainings and other support programs for workers. Republicans were opposing the TAA, considering it to be an 'unnecessary government subsidy'. Finally, after political maneuvers in the House, thanks to a bipartisan coalition formed with a majority of Republicans, the "fast-track" for the president was approved (Lewis, 2015). Democrats were worried about the economical domestic consequences the deal would have had for the US. Whereas Republicans, normally opposers of Obama's policies, were now willing to support president's efforts to negotiate the TPP.

As 2016 Presidential candidates started voicing their opinions on the campaign trail, more fractures emerged within Congress. After Obama signed the agreement in February of 2016, the House and Senate's approval of the agreement seemed to be in question. Senator McConnell, initially supportive of the agreement, expressed caution, and declared that Congress should wait until the end of the elections to vote upon the TPP (Sutter, 2016). Similarly, Rob Portman, who had also voted in favour of 'fast-track', spoke out against the agreement after the signature. The senator who was seeking re-election in a predominantly trade opposed state (Ohio), where Trump had recently won the primary run overwhelmingly, had been a strong supporter of trade agreements in his political journey, and even negotiated some himself (Calmes, 2016b; Hunt, 2016). Democrats too, like House Democrat Levin, reversed their opinion of the Agreement after having supported the negotiation efforts of the Obama administration (Calmes, 2016a). Evidently, now that the presidential campaigns were underway, obtaining congressional approval had become more complicated; this showed how sen- 
sitive Congress was to the election's outcome and public opinion, both crucial for their own re-election (Sutter, 2016). Thereby, as Congress is also part of societal sources of policy making, it can be observed how the public strongly influenced the positions of Congress in this crucial legislative phase for the TPP.

Stronger evidence to support the impact of public opinion upon Congress' attention can be found in the reactions to the first primary results in February, a few days after the signing of the TPP. The victories of Trump and Sanders in New Hampshire, where a large majority of voters of both parties declared feeling that their families where not advancing financially sent a strong signal. Through their ballot, voters were calling for a different economic approach to trade and the global economy (Harwood, 2016). This and other similar primary results, contributed to lowering the chances of Congressmen approving the deal in 2016, especially after seeing key districts prefer candidates with protectionist stances win (Behshudi, 2016). As historical overviews show, Congress is highly sensitive to switches in public opinion, strongly rooted in their concern for re-election (Schmeller, 2016). Hence, the results which had emerged from the first primaries were likely to strike a nerve in Congressmen hearts, due to their susceptibility to changing public opinion.

The last chance for TPP's ratification was the 'lame-duck' Congress Session, which is held after the new president has been elected, but before the end of term of the current administration (United States Senate, n.d.). The Obama administration had hoped that the absence of election pressure would now allow Congressmen to see the policy's importance. The strong will of the administration in advancing the TPP gave many the idea that the president would push for the policy to be approved (Behshudi, 2016; Rampton, 2016). However, shortly before the vote, the White House decided to abandon the policy. The administration had recognised that neither the House nor the Senate had the numbers to approve the agreement and did not submit it for a vote (Yuhas, 2016). While still having supporters on both sides, the agreement was not likely to gain approval, and its survival was threatened by the recent developments of 2016 which had signaled a protectionist wave within public opinion.

Clearly, the TPP was object of concern for Congress members of both parties. While a bipartisan alliance demonstrated clear signs of approval for the policy in June of 2015, as the electoral campaign advanced, the position of Congress changed. The stance of both House and Senate was moulded by increasing public opinion supporting of candidates strongly opposed to the TPP (Behshudi, 2016). This ultimately led the White House to surrender and not push for a vote. In the context of societal sources, Congress had been at the receiving end of an amplified protectionist public stance. 


\section{The role of domestic interest groups}

The TPP was argued to be an important deal for the American Economy. Estimates from 2016 predicted an increase of US exports and large gains for its service sector. The agreement also entailed important provisions related to environmental and property rights protection (Williams, 2013). However, this was foreseen to come at the cost for the manufacturing sector, which was at risk of suffering additional decreases in employment because of further market opening to cheaper imports. Moreover, many concerns were raised against the TPP with respect to pharmaceutical industries protections, weak guarantees for worker's rights, currency manipulation regulations, and many others (Calmes, 2016a; Fergusson, McMinimy, \& Williams, 2015). Within societal sources, US interest groups have significant leverage upon decision-makers, and during the TPP debate, many groups took strong stances on both sides.

Since the beginning of the TPP journey in Congress, business groups and labour unions took an engaged attitude. Interest groups' positions seemed to be clearly divided; overall, corporate companies aimed at influencing the Republican side, while labour unions looked at the Democrats. The U.S. Chamber of Commerce, a lobbying company defending business interests, is one of the largest lobbies in Congress, having invested over \$124 million to influence legislation in 2014. Along with the Pharmaceutical Research and Manufacturers of America, the Chamber of Commerce directed its attention towards the Republican party and the support of the agreement, convincing many to believe that the TPP would pass thanks to large corporate support (Skonieczny, 2017). The overwhelming investment of business groups in support of the TPP at this point seemed to be the key to the success of the deal.

Among the lobbies appealing to Democrats, the most influential opposer of the policy in 2015 was AFL-CIO, a powerful labour union (Mindock, 2015). Democrats were particularly pressured by the union's influence, strongly related to environmental issues and labour protection. As demonstrated by the 2015 July vote, Democrat Congressmen held different opinions. An example of this is Congressman Ami Bera, who declared support for the 'Fast-track'. In response, the AFL-CIO threatened to fund his opponents and made similar promises to other Democrats who held positive attitudes towards trade. Therefore, many within the party were hesitant to back the policy, which partially contributed to the timid support Democrats showed for the policy (Walsh, 2015).

When the agreement text was released in November 2015, the pressure of interest groups changed. One reason was that a larger number of interest groups was now able to scrutinise the text, and was promptly attempting to influence 
decision-making around the TPP. At this point the large corporate investment was being counterbalanced by opposers of the agreement. In addition, early supporters such as the Pharmaceutical Research and Manufacturers of America changed side, as it was not satisfied with the provisions related to its sector (Skonieczny, 2017). Hence, the release of the agreement details challenged the lobby power of TPP supporters, rebalancing the influences upon Congress.

Lastly, the rise of protectionist feelings among the American public underlined in the 2016 elections challenged the corporate interest groups and flipped the situation. Trump's anti-trade tones changed the position of Republicans with regards to trade, and as the party unified to support Trump in the presidential race, the TPP was abandoned by its republican supporters (Skonieczny, 2017). Hence, it was clear that the deal would have not received neither the democratic vote, because of the huge pressures from labour unions and other opposing interest groups, nor the Republican, in defiance of the large corporate donations received in the past from business groups. In the context of societal sources analysis, interest groups clearly became another victim of the overwhelming influence of a media-shaped public opinion.

\section{Conclusion}

During the 2016 elections, international trade seemed to have reach the tipping point of influence. With a large portion of the population leaning towards protectionism, holding the domestic economy as a primary concern, and turning to populist candidates to bring back balance in the US economy, public opinion can be clearly considered to have had a large influence upon trade.

As this paper argued, the public's rise of anti-trade feelings largely affected the 2016 elections, but was amplified and influenced by media. Moreover, public opinion outperformed business interest groups and persuaded Republicans to oppose the TPP. As Obama decided not to push forward the TPP during the 'lame-duck' session, the Trump administration was able to opt-out without difficulty of the agreement. Hence, public opinion, amplified by media, being at the source of Congress' opposition and having trumped major interest groups, has evidently contributed to US' withdraw from the Trans-Pacific Partnership.

American Foreign policy analysis is not a straight-forward process. Many factors contribute to its creation and drafting, and not all factors are always evident to researchers. Similarly, in this analysis many factors might not have been considered, even within the level of analysis which the paper decided to focus upon. Hence, the policy here analysed would benefit from further analysis on 
different levels. External sources to be considered could include the impact of recent trade acceleration experienced with China by the US upon public opinion. Another approach could entail a deeper dive into the evolution of Congress' position with regards to the agreement. In fact, further attention could be devoted to the impact of citizen's protests, which had strongly voiced opposition to the TPP before the elections.

Ultimately, when analysing societal sources of foreign policy, considering several factors is necessary. For this reason, this paper has employed a variety of academic material originating from different disciplines. The consideration of features such as trade competition, electoral media coverage, and Congressional influence analysis was included to achieve a broader understanding of TPP's evolution within US' society. As demonstrated, to understand how societal analysis of foreign policy, scholars can largely profit from multidisciplinary scrutiny, especially considering the intricacies which characterise societies in today's world. Just as policy, people's decisions are not made in a vacuum, but are rather the conflux of a plurality of information, interests, and influence. Hence, novel, open, and multidisciplinary approaches to academic scrutiny can assist in understanding challenges and features of an increasingly complex international system.

\section{References}

Acemoglu, D., Autor, D., Dorn, D., Hanson, G. H., \& Price, B. (2016). Import competition and the great US employment sag of the 2000s. Journal of Labor Economics, 34(S1), S141-S198. doi:10.1086/682384

Autor, D., Dorn, D., Hanson, G., \& Majlesi, K. (2016). A note on the effect of rising trade exposure on the 2016 presidential election. MIT Working Papers. Retrieved from https://economics.mit. edu/files/12418

Baker, P. (2017, January 23). Trump abandons Trans-Pacific Partnership, Obama's signature trade deal. The New York Times. Retrieved from https://www.nytimes.com/2017/01/23/us/politics/tpptrump-trade-nafta.html

Behshudi, A. (2016, December 8). Obama puts Congress on notice: TPP is coming. Politico.

Retrieved from https://www.politico.com/story/2016/08/obama-congress-trade-warning-226952

Butensky, J. (2016). Road to approval: Congressional hurdles for President Obama's Trans-Pacific Partnership. Politico Agreement. Retrieved from http://sites.bu.edu/dome/2016/01/28/road-toapproval-congressional-hurdles-for-president-obamas-trans-pacific-partnership-agreement/

Calmes, J. (2016a, February 18). Michigan democrat opposes Trans-Pacific pact. The New York Times. Retrieved from https://www.nytimes.com/2016/02/19/business/international/michigandemocrat-opposes-trans-pacific-pact.html 
Calmes, J. (2016b, February 4). Senator Rob Portman to oppose Pacific trade pact. The New York Times. Retrieved from https://www.nytimes.com/2016/02/05/business/international/senatorrob-portman-to-oppose-pacific-trade-pact.html

Calmes, J. (2016c, September 21). Who hates free trade treaties? Surprisingly, not voters. The New York Times. Retrieved from https://www.nytimes.com/2016/09/22/us/politics/who-hates-tradetreaties-surprisingly-not-voters.html

Chozick, A., \& Flegenheimer, M. (2016, June 21). Hillary Clinton to pummel Donald Trump on economy, calling him uncaring. The New York Times. Retrieved from https://www.nytimes. com/2016/06/21/us/politics/hillary-clinton-economy-speech.html

Fergusson, I. F., McMinimy, M. A., \& Williams, B. R. (2015). The Trans-Pacific Partnership (TPP) negotiations and issues for congress. Congressional Research Service. Retrieved from https://fas. org/sgp/crs/row/R42694.pdf

Harwood, J. (2016, February 11). U.S. voters strike back against political status quo. The New York Times. Retrieved from https://www.nytimes.com/2016/02/12/us/politics/us-voters-strike-backagainst-political-status-quo.html

Hastendt, G. P. (2017). American Foreign Policy: Past, present and future (1lth edition). Lanham: Rowman \& Littlefield.

Hunt, A. R. (2016, February 21). Trump targets free trade, and G.O.P. follows suit. The New York Times. Retrieved from https://www.nytimes.com/2016/02/22/us/politics/trump-targets-freetrade-and-gop-follows-suit.html

Kaufman, J. P. (2017). A concise history of U.S. foreign policy (4th edition). Lanham: Rowman \& Littlefield.

Lewis, P. (2015, June 24). Barack Obama given 'fast-track' authority over trade deal negotiations. The Guardian. Retrieved from https://www.theguardian.com/us-news/2015/jun/24/barackobama-fast-track-trade-deal-tpp-senate

Lynch, G. P. (1999). Presidential elections and the economy 1872 to 1996: The times they are a 'changin or the song remains the same? Political Research Quarterly, 52(4), 825-844. Retrieved from https://journals.sagepub.com/doi/abs/10.1177/106591299905200408?casa_ token=Zyk26jCRRZUAAAAA:fp-XQzPltBEQlyapA4VqMhJpOIAC_jOTdZuiLwwt9Pg8vb_ N1EQwlkU2tvCGnVnGlyh8CRNU9p4

McBride, J. (2017). The state of U.S. trade policy. Retrieved October 9, 2018, from Council of Foreign Relations https://www.cfr.org/backgrounder/state-us-trade-policy

McCombs, M. (2002). The agenda-setting role of the mass media in the shaping of public opinion. Paper presented at the Mass Media Economics 2002 Conference, London School of Economics.

Retrieved from http://sticerd.lse.ac.uk/dps/extra/McCombs.pdf

Mindock, C. (2015, April 9). Trans-Pacific Partnership deal has mighty lobbying power on its side. OpenSecrets.com. Retrieved from https://www.opensecrets.org/news/2015/04/trans-pacificpartnership-deal-has-mighty-lobbying-power-on-its-side/ 
Patterson, T. E. (2016). News coverage of the 2016 General Election: How the press failed the voters. Harvard Kennedy School. Retrieved from https://research.hks.harvard.edu/publications/ getFile.aspx?Id=1463

Petri, P., \& Plummer, M. (2016). The economic effects of the Trans-Pacific Partnership: New estimates. Peterson Institute for International Economics. Retrieved from https://piie.com/ publications/working-papers/economic-effects-trans-pacific-partnership-new-estimates

Piketty, T. (2016, November 16). We must rethink globalization, or Trumpism will prevail. The Guardian. Retrieved from https://www.theguardian.com/commentisfree/2016/nov/16/ globalization-trump-inequality-thomas-piketty

Rampton, R. (2016). Joe Biden says chances of congress passing the TPP are slim. Reuters. Retrieved from https://www.reuters.com/article/us-usa-trade-biden/biden-sees-less-than-even-chance-ofu-s-congress-approving-tpp-deal-idUSKCN11S03W?il=0

Schmeller, M. G. (2016). Invisible Sovereign: Imagining public opinion from the revolution to reconstruction. Baltimore: JHU Press.

Skonieczny, A. (2017). Corporate lobbying in foreign policy. Oxford Research Encyclopedia of Politics. doi:10.1093/acrefore/9780190228637.013.420.

Sutter, R. (2016). The impact of the 2015-2016 presidential election campaign on American Asian policy debates. Asian Journal of Comparative Politics, 1(4), 354-369. doi:10.1177/2057891116669257

The New York Times. (2015). Americans' views on income inequality and workers' rights [Data set]. CBS News Poll. Retrieved from https://www.nytimes.com/interactive/2015/06/03/business/ income-inequality-workers-rights-international-trade-poll.html?_r $=0$

The New York Times. (2018). Presidential candidates on the Trans-Pacific Partnership. Elections. Retrieved from https://www.nytimes.com/interactive/2016/us/elections/trans-pacificpartnership.html

United States Senate, (2019). Glossary Term | "Lame Duck" Session. Retrieved from https://www. senate.gov/reference/glossary_term/lame_duck_session.htm. Accessed on March 5, 2019

Walsh, D. (2015). Democrats blast unions' pressure tactics on trade. CNN Politics. Retrieved from https://edition.cnn.com/2015/06/03/politics/president-obama-democrats-unions-trade/index. html

Wilder, M. (2015). In search of 'dialectic' process models: From 'funnel of causality' to an integrated theory of policy regimes. Prepared for the CPSA Annual Conference section on Richard Simeon and Studying Public Policy. Retrieved from http://dx.doi.org/10.2139/ssrn.2614531

Wilder, M. (2016). Whither the Funnel of Causality?. Canadian Journal of Political Science/Revue Canadienne de Science Politique, 49(4), 721-741. doi:10.1017/S0008423916001153

Williams, B. R. (2013). Trans-Pacific Partnership (TPP) countries: Comparative trade and economic analysis. Washington, DC: Congressional Research Service. Retrieved from https:// digitalcommons.ilr.cornell.edu/key_workplace/1015/ 
Wittkopf, E. R., Jones, C. M., \& Kegley, C. W. (2007). Pattern and process in American foreign policy: An analytical perspective. In American Foreign Policy: Pattern and Process ( $7^{\text {th }}$ edition., pp. 17-26). Boston: Cengage Learning.

Yuhas, A. (2016, Nov. 13). Congress will abandon Trans-Pacific Partnership deal, White House concedes. The Guardian. Retrieved from https://www.theguardian.com/business/2016/nov/12/ tpp-trade-deal-congress-obama 